\title{
RESPONSE OF LON KIDA (Nauclea orientalis L.) TOWARDS MYCORRHIZAL INOCULUM IN WATERLOGGED CONDITION
}

\author{
FAISAL DANU TUHETERU ${ }^{1,2^{*}}$, CECEP KUSMANA ${ }^{3}$, IRDIKA MANSUR ${ }^{3}$, \\ and ISKANDAR ${ }^{4}$ \\ 'Tropical SilviailtureMajo, Post-graduateSchod of Insitut Petarian Bogr, Bogr 16680, Indonesia \\ ${ }^{2}$ Department of Forestry, Faailty of ForestryandEnmironmental Säere, Halu OleoUniversity, Indonesia \\ ${ }^{3}$ Department of Silvialture Faalty of Forestry, Institut Petanian Boor, Boogr 16680, Indonesia \\ ${ }^{4}$ Department of Säl Säenes andLandResarres Faailty of Agialture, Institut Petanian Bogr, Bogr 16680, Indonesia
}

Received 1 August 2014/ Accepted 6 October 2014

\begin{abstract}
ABST RACT
Waterlogged condition is one of environmental conditions not favorable for plants and mycorrhizal fungi. The tolerant species are more adaptive to waterlogged condition. The documented effects of Arbuscular Mycorrhizal Fungi (AMF) inoculation on wetland plant performance are inconsistent. Besides increasing the tolerance of plants, AMF also causes plants depression in waterlogged condition. This study was carried out to examine the morphoanatomical adaptation, survival, growth, biomass and nutrient uptake of lonkida (NaudeacientalisL.) from different habitats inoculated with Arbuscular Mycorrhizal Fungi (AMF) in waterlogged condition for 90 days. Experiment procedures included: seed germination, preparation of inoculums and inoculation of AMF and waterlogged treatment. The results showed that lonkida seedlings formed lenticels (100\%), adventitious roots (41\%) and aerenchym under waterlogged condition. Seedlings from dry land habitats, both mycorrhizal and non-mycorrhizal, had lower height growth rate than those from other habitat types. The same results happened for relative growth rates for shoot (RGRs), root (RGRr) and total (RGRt) dry weight and the ratio of root shoots. Treatments of temporal swamp habitat without waterlogged condition and with waterlogged condition and treatment in savannah with waterlogged condition had RG Rt greater than those in other treatments. In general, plant dry weight (root, shoot and total) and total $\mathrm{N}$ in roots and shoots were greater in the interaction between temporal swamp habitat with nonmycorrhizal in waterlogged condition. However, lonkida seedling from dry land habitat required AMF under waterlogged condition to improve biomass and $\mathrm{N}$ accumulation in roots. Independently, waterlogged condition increased the pool of average height gain (18\%), diameter (46\%), leaf area (40\%), leaf length (17\%) and leaf width (21\%). Nonetheless, waterlogged condition treatment decreased the number of leaves $(9 \%)$ and AMF colonization (71\%). The results of this study indicated that seedlings from temporal swamp had good growth and high biomass in condition with or without waterlogged condition.
\end{abstract}

Keywords: Arbuscular Mycorrhizal Fungi (AMF), lonkida, morpho-anatomical adaptations, NaudeacientalisL., swamp, waterlogged condition

\section{INTRODUCTION}

Waterlogged is one of environmental conditions not favorable for plants and mycorrhizal fungi (Helgason \& Filters 2009). Waterlogged condition causes anaerobic condition indicated by hypoxia and anoxia (Elzenga \& van Veen 2010). These conditions can affect growth, development and adaptability of plant species (Kreuzwieser \& Gessler 2010;

\footnotetext{
* Corresponding author : faisaldanu_28@yahoo.com
}

Parolin \& Wittman 2010) as well as species composition of forest stands (Kozlowski 1984, 1997). Effects of waterlogged condition is highly varied depending on genetic and age of the plants, time and duration of inundation (Kozlowski 1984) as well as depth of inundation (Iwanaga \& Yamamoto 2008). Plant can tolerate waterlogged condition through morpho-anatomical and physiological adaptation mechanisms. Physiological adaptation can be done by accumulating reserves in the root in the form of carbohydrates and alcohol fermentation as an 
alternative (Kreuzwieser \& Gessler 2010; Parolin \& Wittman 2010), while morpho-anatomical adaptation is done by forming lenticels, adventitious roots and aerenchyma (Folzer $\& \mathrm{al}$. 2006; Parolin \& Wittman 2010).

Plant tolerance to waterlogged condition varies and is determined by the species (Kozlowski 1984). The tolerant species are more adaptive to waterlogged condition (Kogawara \& al. 2006). However, differences in habitat of the species also largely determine the success of the plant to survive in inundation condition (Ferreira $\& \mathrm{al}$. 2009; Nielsen $\notin$ al. 2010). Several studies have reported that species growing naturally in the inundated area are more tolerant to waterlogged condition, such as Nyssa sytatica (Keeley 1980), female Populus angostifdia (Nielsen \&al. 2010) and Himatanthus suauba (Ferreira \& al. 2009). Information on tropical species tolerance and adaptation to inundation still needs to be studied (Parolin 2009). In Indonesia, research on tolerant species toward different types of inundated habitat is still very limited.

Lonkida (Naudea cietalis L.) is a tropical multipurpose tree species that grows naturally in a variety of habitat types including wetlands (Petty \& D ouglas 2010; Kartikasari \& al. 2012) and has natural distribution in Indonesia (Whitmore $\notin \mathrm{al}$. 1997; Keßler \&al. 2002). This species has potential uses for agroforestry, phytoremediation and rehabilitation of degraded land, including wetlands (Marghescu 2001; Amihan-Vega \& Mendoza 2005; Mawaddah 2012) and medicinal plant (Lim 2013). A preliminary study of lonkida response to waterlogged condition in greenhouse scale had been conducted and it was confirmed that this species was tolerant to waterlogged condition (Kurniawati 2011). However, studies related to growth response, adaptation, and plant nutrient uptake ability of lonkida from various habitats under waterlogged condition had not been reported.

This species was also reported to be colonized by Arbuscular Mycorrhizal Fungi (AMF) Gloms mose in India (Sudha \& Ammani 2010) and showed good growth response to the application of AMF in waterlogged condition (Kurniawati 2011). Tolerance to waterlogged condition could be enhanced through AMF inoculation. Association of inundated plants with AMF is part of strategy to improve nutrient uptake and oxygen circulation (Elzenga \& van Veen 2010). In waterlogged condition, AMF association could improve growth (O sundina 1998; Fougnies $\&$ al. 2007), biomass and nutrient uptake, especially phosphorus (Muok \& Ishii 2006; Fougnies \& al. 2007), the growth of root systems (Q iang-Sheng etal. 2013) and the structure of plant communities (Bauer \& al. 2003). However, colonization, abundance and benefits of AMF in waterlogged condition can vary among plant species (Bauer $\mathrm{A}$ al. 2003) due to species of AMF used (Secilia \& Bagyaraj, 1994; Sah \& al. 2006), availability of phosphorus (Stevens \&al. 2002; G arcia đal. 2008) and distance from the AMF rhizospher (Keeley 1980). Biomass of mycorrhizal Nyssa sivatica seedlings from inundated seed sources were higher than that from dry areas (Keeley 1980).

The purpose of this study was to examine the morpho-anatomical adaptation, survival, growth, biomass production and nutrient uptake of AMFinoculated lonkida originated from different habitat types in waterlogged condition.

\section{MATERIALS AND METHODS}

\section{ExperimentProcedures}

\section{Seetgemination}

Lonkida seeds were collected from mother trees grown in different habitat types (swamps, temporary swamps, temporary swamps savannah and dry land areas) in Kendari City, Konawe and South Konawe District (Fig. 1), Southeast Sulawesi Province. Lonkida seeds were germinated in plastic boxes having dimension of 20x20x5 cm containing sterile soil media $( \pm 1 \mathrm{~kg})$ and were grown until reaching seedling stage at age of 150 days before being used in this experiment. There were 144 seedlings ready to be used in this experiment.

\section{InoulumpreparationandAMFinoulation}

AMF inoculum used was mycofer IPB containing 4 (four) species of AMF, namely Gloms euricatum Gloms manihntis Acaulospora tuberalataand Gigasparamarganita The number of spores per $5 \mathrm{~g}$ of inoculum was 57-125 spores. Before AMF inoculation, polybags having size of $15 \times 20 \mathrm{~cm}$ were filled with sterile soil media $(1.5 \mathrm{~kg}$ soil media/ bag). There were 72 lonkida seedlings having age of 150 days inoculated with AMF inoculum and subsequently were called mycorrhizal seedlings. The other 72 lonkida 


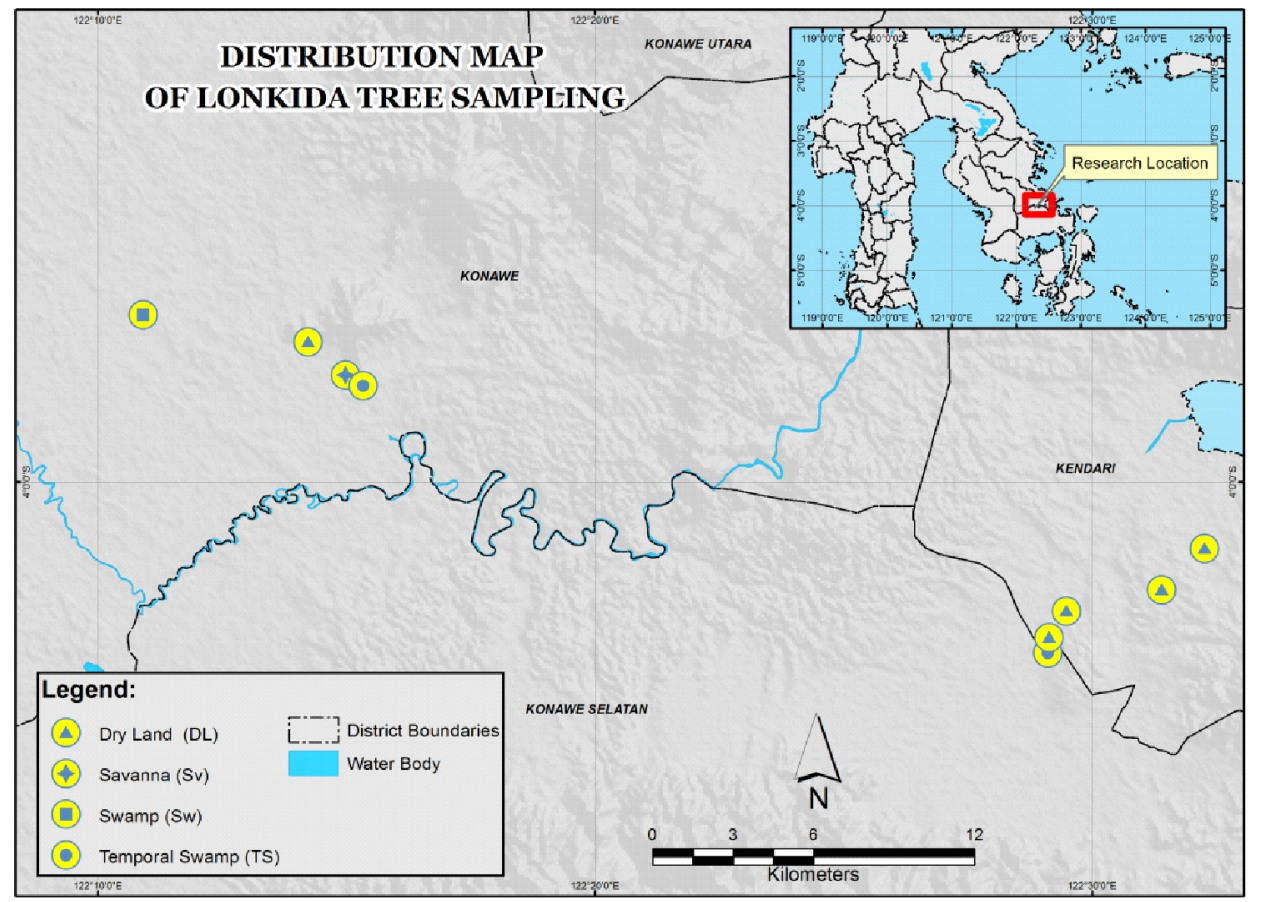

Figure 1. D istribution map of lonkida tree sampling

seedlings were not inoculated with $\mathrm{AMF}$ inoculum and served as control treatment; subsequently were called non-mycorrhizal seedlings. Chemical properties of the sterile soil media were $\mathrm{pH} 5.2$, organic $\mathrm{C}$ (Walkey \& Black) $0.27 \%$, total $\mathrm{N}$ (Kjeldahl) $0.06 \%, \mathrm{C} / \mathrm{N}$ ratio 5 , available P (Bray I/ II) 2.5 ppm, exchangeable $\mathrm{Ca}$, $\mathrm{Mg}, \mathrm{K}, \mathrm{Na}$, and CEC were $10.32 \mathrm{cmol} / \mathrm{kg}, 1.49$ $\mathrm{cmol} / \mathrm{kg}, 0.66 \mathrm{cmol} / \mathrm{kg}, 1.76 \mathrm{cmol} / \mathrm{kg}$ and 19.79 $\mathrm{cmol} / \mathrm{kg}$ (Extract Buffer $1.0 \mathrm{~N} \mathrm{NH}_{4} \mathrm{OAc} \mathrm{pH} \mathrm{7.0),}$ respectively.

\section{Watedoggeettreatment}

Mycorrhizal and non-mycorrhizal seedlings at age of 150 days after planting were then treated with waterlogged condition. Each seedling was placed in a polybag having size of $26.5 \times 23 \mathrm{~cm}$ containing sterile soil media. A total of 72 seedlings inside polybags were immersed in water, while the other 72 seedlings inside polybags were not immersed, but watered every day as control (Garcia \& al. 2008). Water level was monitored every 3 days.

\section{Expeimetal design}

This study used factorial in a completely randomized design (CRD) consisting of 3 factors:

1. Treatment $A=$ habitat origin of lonkida consisted of:

$\mathrm{A}_{0}=$ dryland;

$\mathrm{A}_{1}=$ swamp;
$\mathrm{A}_{2}=$ temporal swamp;

$\mathrm{A}_{3}=$ temporal swamp savannah.

2. Treatment $\mathrm{B}=\mathrm{AMF}$ inoculum treatment consisted of:

$\mathrm{B}_{0}=$ uninoculated (non-mycorrhizal);

$\mathrm{B}_{1}=$ inoculated with $\mathrm{AMF}$ inoculum (mycorrhizal).

3. Treatment $\mathrm{C}=$ waterlogged treatment consisted of:

$\mathrm{C}_{0}=$ control (non-waterlogged);

$\mathrm{C}_{1}=$ waterlogged.

Each treatment was replicated 3 times and each replication consisted of 3 test plants. The experiment was conducted for 90 days. At the end of experiment, the seedlings' age was 240 days old.

\section{Data Collection}

\section{Grouth}

Measurements were conducted at the end of the experiment (at the end the 90-day experiment) for seedling height, seedling diameter, number of leaves per seedling and plant survival. Measurement of leaf area was conducted using green leaf area meter GA-5 model. Relative growth rates (RGR) for total (RGTt), shoots (RGTs) and roots (RG Tr) dry mass for control and waterlogged condition were then calculated using the formula of Mendoza eal. (2005): 
$\mathrm{RGRi}=\left(\ln \mathrm{W} \mathrm{t}_{\mathrm{f}}-\ln \mathrm{Wt} \mathrm{t}_{0}\right) /\left(\mathrm{t}_{\mathrm{f}}-\mathrm{t}_{0}\right)$

where:

$\mathrm{RG} \mathrm{R}=$ relative growth rate of plants;

$\mathrm{i}=$ total dry weight, shoots and roots;

$\mathrm{Wt}_{\mathrm{f}}=$ plant dry weight (total, shoots and roots) at the end of the experiment (seedlings' age was 240 days old);

$\mathrm{Wt}_{0}=$ plant dry weight at the beginning of experiment period (seedlings' age was 150 days old);

$t_{\mathrm{f}}-t_{0}=$ the difference between the initial and the total period of growth (experiment period was 90 days).

\section{Drywightandnutrientsinplanttissue}

At the end of 90 days, the shoots and roots were harvested. Fresh shoots and roots were ovendried at $70^{\circ} \mathrm{C}$ for 48 hours (G arcia etal. 2008). D etermination of $\mathrm{P}$ was carried out using $\mathrm{HNO}_{3}-$ $\mathrm{HClO}_{4}$ method, and $\mathrm{N}$ by Kjeldahl (Balai Penelitian Tanah 2009). For $\mathrm{N}$ and $\mathrm{P}$, two expressions of nutrient uptake efficiency was calculated i.e. concentration per unit of dryweight and total (accumulation) uptake per unit of dry weight.

\section{Morphoanatomical adaptation}

Observation and counting of the number of lenticels and adventitious roots were done every week using non-destructive samples. The data of lenticels and adventitious roots were obtained at the end of experiment. The proportion data of lenticels number and adventitious roots were the ratio between the number of samples forming lenticels and adventitious roots. Aerenchyma observations for the lenticles and adventitious roots were made by following the method of freezing microtome (Longstreth 1879). Roots of 3 $\mathrm{cm}$ long (diameter $<3 \mathrm{~mm}$ ) were immersed in $70 \%$ alcohol solution (24 hours). The roots were then cut using scissors into root pieces of $0.5 \mathrm{~cm}$ long. The root pieces were then put in Yamato Mc802A Electro Freezer for $2-3$ minutes at $-15^{\circ} \mathrm{C}$. The roots were then cut using Yamato RV-240 microtome with thickness of $20 \mu \mathrm{m}$. Before the roots were placed on object glasses, several drops of $20 \%$ glycerol solution were applied on the object glasses, while the roots were stained with safranin. Aerenchyma observation was made using Axio Imager microscope A1m/ Axiocam MRc5 (200x magnification).

\section{SusceptibilityIndex (SI)}

For all measured plants and soil variables, Susceptibility Index (SI) was calculated using the method of Hiler \&al. (1972):

SI = 1 - (waterlogged plant/ non-waterlogged plant)

SI value will be positive if the waterlogged condition decreases the variables measured. On the other hand, SI value will be negative if waterlogged condition increases the variables measured.

\section{AMF sparedansityandcolonization}

Thirty grams of soil samples were collected from soil medium in polybags used as mychorrizal lonkida medium. Spores were extracted from soil using wet sieving and decanting method (Gerdemann \& Nicolson 1963) followed by centrifugation; supernatant acquired was added with 50\% sugar solution (Walker eal. 1982). AMF spores extracted were observed and counted under a dissecting microscope with $35 \mathrm{x}$ magnification. Root colonization was observed by using root staining technique of Brundrett $\notin a$ al. (1996). Fresh roots were cleaned in $10 \% \mathrm{KO} \mathrm{H}$ for 2 days, then were immersed in $\mathrm{H}_{2} \mathrm{O}_{2}$ for $10-20$ minutes and were rinsed thoroughly with water. The roots were then soaked in $\mathrm{HCl} 0.2 \%$ for 20 minutes and then were stained with trypan Blue solution $(0.05 \%)$. Ten root samples (1 cm long) from each plant were observed under a microscope with 200x magnification. Root colonization was calculated using the formula of Brundrett \&al. (1996):

$\%$ root colonization =

Number of fields-of-view containing mycorrhizae $\mathrm{x}$ 100\% Total observed fields-of-view

\section{Data Analysis}

D ata were analyzed using analysis of variance (ANOVA). Abnormal data were normalized using logarithmic transformation. The data were further analyzed using D uncan's multiple range test (DMRT) for means comparison. D ata analyses were computed using SAS 9.1.3 portable program. 


\section{RESULTS AND DISCUSSION}

\section{Morpho-AnatomicalAdaptation}

Seedlings of lonkida have morpho-anatomical adaptation mechanisms to survive in waterlogged condition. Theresults showed that lonkida seedlings produced adventitious roots, lenticels and aerenchyma (Fig. 2 and Table 1). Lenticels began to form within 3 to 5 days after being in the waterlogged condition. All seedlings under waterlogged condition formed $100 \%$ lenticels (Table 1). Lonkida seedlings grown in
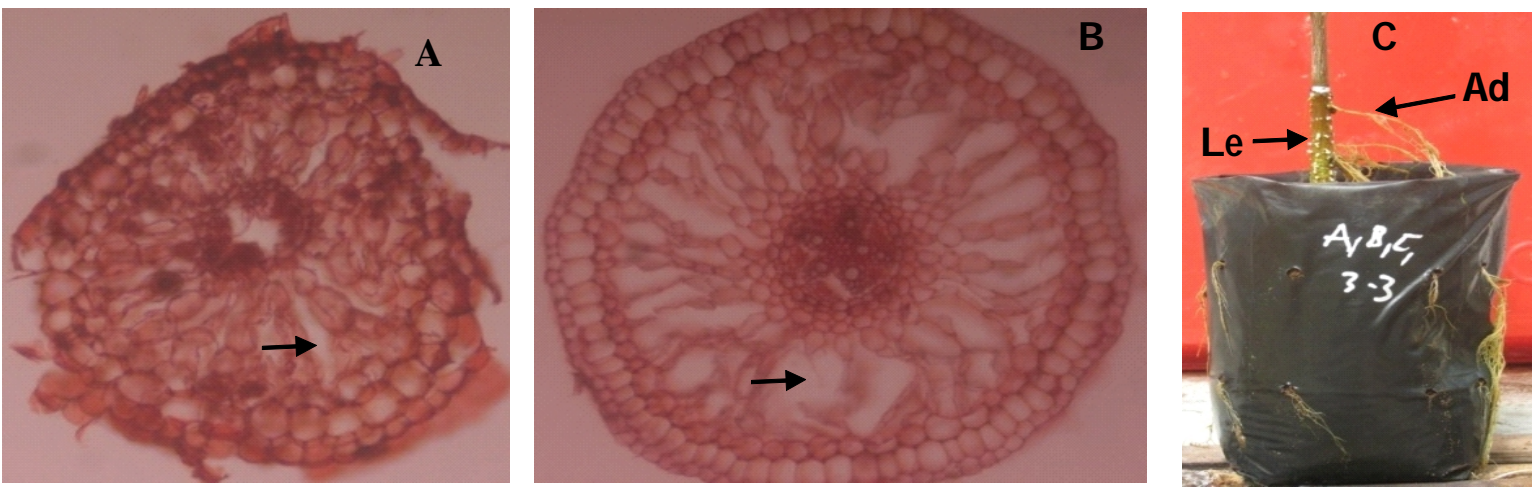

Figure 2. Cross-section of lonkida root tissue (x200 magnification) showing the presence of aerenchyma in (A) nonwaterlogged condition; (B) waterlogged condition; (C) formation of lenticels (Le) and adventitious roots (Ad)

Table1. Measurement of the observed variables for lonkida seedlings grown in waterlogged condition and in nonwaterlogged condition

\begin{tabular}{|c|c|c|c|c|}
\hline Variables & $\begin{array}{l}\text { Measurement for lonkida } \\
\text { seedlings grown in } \\
\text { waterlogged condition } \\
(\text { mean } \pm \text { SE })\end{array}$ & $\begin{array}{c}\text { Measurement for } \\
\text { lonkida seedlings grown } \\
\text { in non-waterlogged } \\
\text { condition } \\
\text { (mean } \pm \text { SE) }\end{array}$ & SI & $\begin{array}{l}\text { Effect of } \\
\text { waterlogged } \\
\text { condition }\end{array}$ \\
\hline \multicolumn{5}{|l|}{ Plant growth variables } \\
\hline Survival & $100 \pm 0.00 \quad \mathrm{a}$ & $100 \pm 0.00 \quad \mathrm{a}$ & ns & ns \\
\hline Height (cm) & $8.13 \pm 2.45 \quad \mathrm{a}$ & $6.18 \pm 1.177 \mathrm{~b}$ & -0.32 & + \\
\hline Diameter $(\mathrm{mm})$ & $1.81 \pm 0.31 \quad \mathrm{a}$ & $1.24 \pm 0.25 \mathrm{~b}$ & -0.46 & + \\
\hline Total of leaves (blade) & $13.1 \pm 0.838 \mathrm{~b}$ & $14.3 \pm 1.183$ а & 0.09 & - \\
\hline Leaf area $\left(\mathrm{cm}^{2}\right)$ & $9.8 \pm 3.045 \quad \mathrm{a}$ & $7.0 \pm 0.659 \quad b$ & -0.40 & + \\
\hline Leaf length $(\mathrm{cm})$ & $8.2 \pm 0.878 \quad$ a & $7.0 \pm 0.363 \mathrm{~b}$ & -0.17 & + \\
\hline Leaf width $(\mathrm{cm})$ & $2.9 \pm 0.431 \quad \mathrm{a}$ & $2.4 \pm 0.132 \mathrm{~b}$ & -0.21 & + \\
\hline RG Rs (per day) & $0.0084 \pm 0.0032 \quad \mathrm{a}$ & $0.0060 \pm 0.0015 \mathrm{~b}$ & -0.42 & + \\
\hline RG Rr ( per day) & $0.0075 \pm 0.0035 \quad \mathrm{a}$ & $0.0069 \pm 0.0020 \quad \mathrm{a}$ & ns & ns \\
\hline Shoot/ root ratio & $1.89 \pm 0.25 \quad \mathrm{a}$ & $1.77 \pm 0.32 \quad \mathrm{a}$ & ns & ns \\
\hline \multicolumn{5}{|c|}{ Adaptation to watelogged condition } \\
\hline Total adventious root & $1.16 \pm 0.552 \quad \mathrm{a}$ & $0.0 \pm 0.00 \mathrm{~b}$ & - & + \\
\hline Adventious root (\%) & $48.6 \pm 17.005 \quad \mathrm{a}$ & $0.0 \pm 0.00 \mathrm{~b}$ & - & + \\
\hline Total lenticels & $30.9 \pm 2.91 \quad \mathrm{a}$ & $1.3 \pm 0.35 \mathrm{~b}$ & -22.7 & + \\
\hline Lenticels (\%) & $100 \pm 0.00 \quad \mathrm{a}$ & $81 \pm 16.95$ b & -0.23 & + \\
\hline \multicolumn{5}{|l|}{ AMF synbiosis } \\
\hline AMF colonization (\%) & $11.5 \pm 2.64 \mathrm{~b}$ & $29.1 \pm 6.25 \mathrm{~b}$ & 0.61 & - \\
\hline \multicolumn{5}{|l|}{ Nutrient uptake } \\
\hline $\mathrm{N}$ in $\operatorname{root}(\%)$ & $1.091 \pm 0.13 \quad \mathrm{a}$ & $1.185 \pm 0.10 \quad \mathrm{a}$ & ns & ns \\
\hline $\mathrm{N}$ in shoot (\%) & $0.73 \pm 0.059 \mathrm{~b}$ & $0.83 \pm 0.061 \quad \mathrm{a}$ & 0.12 & \\
\hline $\mathrm{P}$ in root $(\%)$ & $0.208 \pm 0.14 \quad$ a & $0.203 \pm 0.016 \quad \mathrm{a}$ & ns & ns \\
\hline Total $\mathrm{P}$ in root (mg) & $0.255 \pm 0.05 \quad \mathrm{a}$ & $0.199 \pm 0.033 \mathrm{~b}$ & -0.28 & + \\
\hline $\mathrm{P}$ in shoot $(\%)$ & $0.124 \pm 0.02 \quad a$ & $0.108 \pm 0.013 \quad \mathrm{a}$ & ns & ns \\
\hline Total $P$ in shoot $(\mathrm{mg})$ & $0.276 \pm 0.11 \quad \mathrm{a}$ & $0.178 \pm 0.029 \mathrm{~b}$ & -0.55 & + \\
\hline
\end{tabular}

Notes:

1) Figures followed by the sameletters in different columns are not significantly different according to D MRT at $95 \%$ confidence level

2) $n s=$ not significantly different

3) SI/ Susceptibility index = 1-(waterlogged plant/ non-waterlogged plant) 


\section{RESULTS AND DISCUSSION}

\section{Morpho-Anatomical Adaptation}

Seedlings of lonkida have morpho-anatomical adaptation mechanisms to survive in waterlogged condition. The results showed that lonkida seedlings produced adventitious roots, lenticels and aerenchyma (Fig. 2 and Table 1). Lenticels began to form within 3 to 5 days after being in the waterlogged condition. All seedlings under waterlogged condition formed 100\% lenticels (Table 1). Lonkida seedlings grown in waterlogged condition had an increase in lenticels and adventitious roots compared with lonkida seedlings grown in non-waterlogged condition (Table 1). Aerenchyma was formed in the root cortex of lonkida in both waterlogged and nonwaterlogged conditions. A erenchyma proportion in root tissue of lonkida grown in waterlogged condition was greater than that of lonkida grown in non-waterlogged condition (Fig. 2).

Seedlings of lonkida adapted to waterlogged condition by modifying the morphology and anatomy of the body through lenticels, adventitious root and aerenchyma formations. In the treatment where lonkida seedlings were grown in non-waterlogged condition and swamp habitat, the lenticels percentage was below $100 \%$. The same finding was found in aerenchyma in root tissue. Adventitious root formation were absent in treatment where lonkida seedlings were grown in non-waterlogged condition. The adaptation mechanism improves the oxygen uptake ability and oxygen transfer to plant tissues in waterlogged condition (Yin \& al. 2012). Thus, morphological and anatomical adaptations could reduce hypoxic condition and contribute to the restoration and maintenance of aerobic respiration of seedlings in waterlogged condition (Ashraf 2012). Lenticels were crucial in the diffusion of oxygen and anaerobic metabolism resulting products (ethanol, $\mathrm{CO}_{2}$ and $\mathrm{CH}_{4}$ ) and played a role in plant water homeostasis (Ashraf 2012). The adventitious root of plants tolerant to waterlogged condition was formed to play the role as the main root replacement to maintain water and mineral supplies when the main roots were not functioning normally, to maintain aerobic respiration of seedlings and to initiate stomata opening (Kozlowski 1997; A shraf 2012). Network of aerenchyma contributed to the life and growth of plants in a long term waterlogged condition (Ashraf 2012).

Adaptation mechanisms mentioned above were found both in plants tolerant or intolerant to waterlogged condition. Lenticels and adventitious root were found in woody plant, such as Calophtlumbrasilienses Camb (de O liveira \& Joly 2010), Erythinaspeciosa(Medina etal. 2009), Lanix lariana (Islam \& Macdonald 2004), Populus ddtaids(Béjaoui \&al. 2012), Salix gaailistyla(Nakai et al. 2010) and Salix martiana (Parolin 2009). A erenchyma formation in root also occurs in Erythina speciosa (Medina \& al. 2009), Melalera cajuputi (Tanaka \& al. 2011) and Queaus petrae (Folzer \& al. 2006). In addition to the above mechanisms, the roots of lonkida seedlings also appeared on the surface of the media and out through the holed polybags. These facts indicated that the roots could grow well in waterlogged condition and could absorb oxygen and nutrients for the plants. The formation of leaves and roots in waterlogged condition was thought to support growth through the activity of oxygen uptake, increased water and nutrient contents and increased photosynthesis activity (Kozlowski 1997). Increased seedling growth in waterlogged condition indicated that lonkida seedlings had high efficiency in the improvement of biomass per each nutrient absorbed and maintained aerobic respiration (Kozlowski 1997; Tanaka \&al. 2011).

\section{Plant Growth}

Height of lonkida seedlings in temporal swamp and savannah habitats without mycorrhiza showed significant difference from other treatments, except for treatment in swamp habitats either with or without mycorrhiza (Fig. 3a). Lonkida seedlings grew better in waterlogged condition compared with those in non-waterlogged condition, with height growth differences of $32 \%$, diameter differences of $46 \%$, leaf area differences of $40 \%$, leaf length differences of $17 \%$ and leaf width differences of $21 \%$ between the two treatments (Table 1). Nonetheless, waterlogged condition reduced the number of leaves by $9 \%$. Temporal swamp habitat on waterlogged condition had the highest RGRt value $(0.0125 \mathrm{~g} /$ day) and the lowest RGRt value occurred in the dry land under waterlogged condition ( $0.0047 \mathrm{~g} /$ day) (Fig. 3b). Treatment of 
waterlogged condition did not significantly affect RGRr, but RGRs increased by $42 \%$ (Table 1). Non-mycorrhizal lonkida seedlings had higher RGRs, RGRr and RGRt compared with mycorrhizal lonkida seedlings (Table 3). The results of this study indicated that waterlogged condition did not inhibit vertical growth (root and shoot) and horizontal growth (diameter) of plant.

Lonkida seedlings originated from dry land habitats have lower height growth rate, RG Rs, RG Rr, RG Rt and root shoot ratio compared with lonkida seedlings originated from other habitat types, for both mycorrhizal and non-mycorrhizal treatments. The results of this study indicated that lonkida seedlings originated from dry land habitat were not suitable to be planted in waterlogged condition. Several studies have reported the same results, such as study on the female Populus angusifdia that grew naturally in inundated area was more tolerant to waterlogged condition within 15 weeks compared to male P. angustifdia male which originated from the dry land (Nielsen \& al. 2010). Ferreira $\&$ al. (2009) reported that Himatanthus sucuba originated from non-flooded areas (terra-firme) was intolerant to waterlogged condition compared with that originated from inundated area (Varzea) in Amazonian flood plain. However, shoot root ratio of seedlings originated from dry habitats were smaller than those from other habitats. The low shoot root ratio was assumed as being a protective mechanism from dehydration through transpiration (van Splunder eal. 1996). A nother strategy that might occur was that seedlings from dry land habitats had more $\mathrm{C}$ translocation to the roots than to the shoots (Martinez \&al. 2012).

In contrast to the dry habitats, lonkida seedlings originated from temporal swamp habitat in waterlogged and non-waterlogged conditions and lonkida seedlings originated from savannah habitat in waterlogged condition had greater RG Rt compared with RG Rt in other treatments. The average height growth of lonkida seedlings from temporal swamp and savannah habitats were quite high, indicating that lonkida seedlings from both habitats were tolerant to waterlogged condition; which also indicated that the physiological adaptation mechanism of the seedlings was not disrupted and morphoanatomical change was formed well in the waterlogged condition. In addition, lonkida seedlings in the temporal swamp grew well in dry condition and in waterlogged condition. Parolin (2009) explained that the differences in the type of tolerance to waterlogged condition were strongly associated with ecotype differences among habitats due to natural selection. The results of this experiment indicated that lonkida is a species having relatively broad ecological distribution, compared to most species from inundated area, which generally had relatively small ecological amplitude (Parolin 2009).

\section{Plant Biomass}

Table 2 shows significant difference on shoot dry weight was shown for mychorrizal lonkida seedlings originated from dry land in waterlogged condition, non-mychorrizal lonkida seedlings originated from swamp in waterlogged condition, non-mycorrhizal lonkida seedlings originated from savannah in waterlogged condition and mycorrhizal lonkida seedlings originated from savannah in non-waterlogged condition. The same table also shows that root dry weight of mycorrhizal lonkida seedlings originated from dry land in waterlogged condition was significantly different from all other treatments. Significant difference on total dry weight was shown for mycorrhizal lonkida seedlings originated from dry land in waterlogged condition, non-mycorrhizal lonkida seedlings originated from savannah in waterlogged condition and mycorrhizal lonkida seedlings originated from savannah in nonwaterlogged condition (Table 2). Shoot-root ratio of non-mycorrhizal lonkida seedlings was higher (1.95) than that of mycorrhizal lonkida seedlings (1.65) (Table 3).

The results of this study showed that lonkida seedlings had various adaptation strategies to overcome environmental stress. Seedlings from dry habitats required mycorrhizae fungi in waterlogged condition. Some studies also indicated that AMF improved plant tolerance in waterlogged condition (O sundina 1998; Neto \& al. 2006; Fougnies \&al. 2007).T he role of AMF in waterlogged condition can be seen from increase of nutrient uptake especially P (Stevens etal. 2002; Muok and Ishii 2006; Fougnies \&al. 2007; G arcia \& al. 2008) in enhancing growth (Secilia \& 

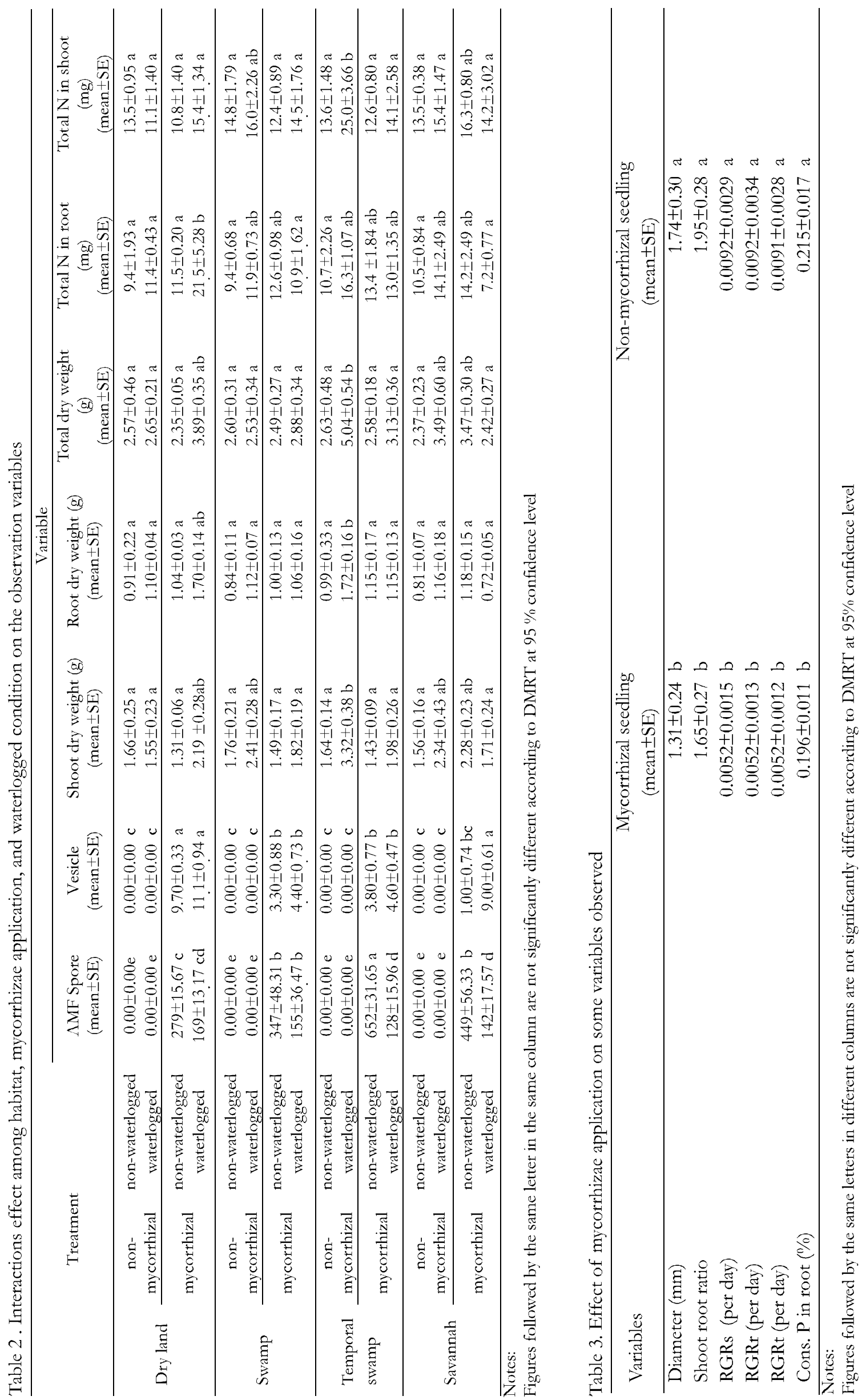
Bagyaraj 1994; Osundina 1998; Fougnies \& al. 2007) and plant biomass (Keeley 1980; Secilia \& Bagyaraj 1994).

\section{Nutrient Uptake}

The highest total $\mathrm{N}$ in root occurred in mycorrhizal lonkida seedlings originated from dry land habitat in waterlogged condition. The highest total $\mathrm{N}$ in shoot occurred in non-mycorrhizal lonkida seedlings originated from temporal swamp in waterlogged condition (Table 2). The results of this study revealed that AMF was needed by seedlings of dry land habitat in waterlogged condition. $\mathrm{N}$ uptake by $\mathrm{AMF}$ in waterlogged condition had also been reported in Astertripdium(Neto eal. 2006). In contrast to the dry habitats, seedlings of temporal swamp habitat did not require mycorrhizae in waterlogged condition. Non-mycorrhizal lonkinda seedlings from temporal swamp in waterlogged condition had higher $\mathrm{N}$ accumulation in leaves and roots. Total P in root of lonkida seedlings grown in waterlogged condition was higher than that of lonkida seedlings grown in non-waterlogged condition (Table 1) which was in line with research on plants of Lotus Glaber Mill. (Mendoza \& al. 2005; G arcia eal. 2008).

\section{Arbuscular Mycorrhizal Fungi (AMF) Colonization and Spore Density}

Arbuscular mycorrhizal fungi (AMF) colonization in waterlogged condition was $61 \%$ lower than that in non-waterlogged condition (Table 1). AMF structures found in the roots of lonkida were internal hyphae, external hyphae, hyphal coils, vesicles and arbuscular. The internal structure of the AMF hyphae was commonly good without waterlogged condition. The numbers of vesicles per $1 \mathrm{~cm}$ roots were more in lonkida seedlings grown in waterlogged condition (Table 2). Waterlogged condition inhibited colonization and spore density of AMF. AMF colonization was believed to decrease the density of spores in waterlogged condition due to anaerobic environment (Escudero \& Mendoza 2005; Mendoza \& al. 2005; Garcia \& al. 2008; Stevens \& al. 2011; Wu \& al. 2013). The low number of spores in this study attributed to the fact that the species of AMF used were not originated from areas with waterlogged condition (Qiang-Sheng $\&$ al. 2013), or oxygen -deficient condition (Kozlowski 1997), or had limited supply of C from the host (Neto etal. 2006). Thus, the AMF was not able to sporulate and had limited external hyphae resulting from waterlogged condition (Secilia \& Bagyaraj 1994; Sah \& al. 2006). Nevertheless, other studies showed higher colonization of AMF in waterlogged condition (Sah \&al. 2006; Neto \&al. 2006; Faougnies \& al. 2007). In addition to the species of AMF, plant species (Bauer \&al. 2003), availability of P (Stevens $\&$ al. 2002; G arcia $\notin$ al. 2008), distance from the AMF rhizospher (Keeley 1980) as well as depth and duration of waterlogged condition also contributed to the AMF symbiosis (G raham \&al. 2013).

Arbuscular mycorrhizal structure found were the internal and external hyphae, vesicles, arbuscular, coil and spores. Arbuscules found and the numbers of vesicles per $\mathrm{cm}$ root were more in waterlogged condition than in non-waterlogged condition. Arbuscule is a structure of AMF in the root that acts as a terminal for the transfer of nutrients from the host to the AMF and the transfer of carbon to fungi (Smith \& Read 2008). Vesicles are storage structures and can support the growth of the internal hyphae (Smith \& Read 2008). In waterlogged condition, vesicle structures were found in large quantities. The results of this study indicated that the AMF saved a lot of energy in the vesicles needed to adapt to the waterlogged condition (Garcia \& al. 2008). This fact had also been reported in the roots of Lous tenuis (Mendoza $\notin$ al. 2005) and Citrusjumos (Qiang-Sheng $\&$ al. 2013). Low number of arbuscules in the root of lonkida also showed that the transfer of $\mathrm{C}$ from plants to fungi was low and inhibited sporulation process

\section{CONCLUSIONS}

Lonkida seedlings had high survival rate and adapted to waterlogged condition by modifying the morpho-anatomical through formation of lenticels, adventitious roots and aerenchyma. Lonkida seedlings from inundated habitat tended to have higher growth and biomass. In waterlogged condition, AMF treatment increased biomass and $\mathrm{N}$ accumulation in roots of lonkida seedlings originated from dry land habitat. A rbuscular mycorrhizal fungi (AMF) colonization in waterlogged condition was lower 
than that in non-waterlogged condition. Based on these results, lonkida has the potential to be used for rehabilitating degraded mininglands.

\section{REFERENCES}

Amihan-Vega B, Mendoza JD. 2005. Benefits from tree growing In the degraded uplands: empirical realities from Tabango, Leyte, thePhilippines. In: Harrison S, Herbohn J, Suh J, Mangaoang E,Vanclay J,editors. ACIAR Smallholder Forestry ProjectRedevelopment of a Timber Industry Following Extensive Land Clearing : Proceedings from The End-of-Project Workshop. Ormoc city, The Philipines, 19-21 August 2004. p 93-106.

Ashraf MA. 2012. Waterlogging stress in plants : a review. AfrJ Agric Res. 7(13): 1976-81.

Balai Penelitian Tanah. 2009. Peunjuk Tknis Analisis Kimia Tanah Tanaman, Air dan Pupuk. Bogor (ID) : Balai Besar Litbang Sumber Daya Lahan Pertanian, Balai Penelitian dan Pengembangan Pertanian Departemen Pertanian.

Bauer CR, Kellogg CH, Bridgham SD, Lamberti GA. 2003. Mycorrhizal colonization across hydrologic gradients in restored and reference freshwater wetlands. Wetlands 23(4):961-68.

BéjaouiZ, Albouchi A, Lamhamedi MS, Abassi M, El Aouni MH. 2012. Adaptation and morpho-physiology of three PopulusddtadesMarsh. x P.NigaL. Clones after preconditioning to prolonged waterlogging. Agroforest Syst 86:433-42.

Brundrett M, N Bougher, B Deu, T Grove, Majalaczuk. 1996. Working with Mycomizas in Forestry and Agiaulture Canberra (AU) : Australian Centre for International Agriculture Research.

de Oliveira VC, Joly CA. 2010. Flooding tolerance of Calophyllum brasiliense Camb. (Clusiaceae): morphological, physiological and growth responses. Trees24:185-93.

Elzenga JTM, van Veen H. 2010.Waterlogging and plant nutrient uptake. In : Mancuso S, Shabala S, editor. Watelooging Signalling and Tderance in Plants New York(US): Springer. p 23-36.

Escudero V, Mendoza R. 2005. Seasonal variation of arbuscular mycorrhizal fungi in temperategrasslands along a wide hydrologic gradient. Mycorrhiza 15: 291-99.

Ferreira C da Silva, Piedade MTF, Tine MAS, Rossatto D R, Parolin P, Buckeridge MS. 2009. The role of carbohydrates in seed germination and seedling establishment of Himatanthussuauka, an Amazonian tree with populations adapted to flooded and nonflooded condition. Ann Bot. 104: 1111-19.
Folzer H, DatJF, Capelli N, Rieffel D, BadotPM. 2006. Response of sessile oak seedlings (Queaus petraa) to flooding: an integrated study. Tree Physiol. 26:75966.

Fougnies L, Renciot S, Muller F, Plenchette C, Prin Y, de Faria SM, BouvetJM, Nd Sylla S, D reyfus B, BâAM. 2007. Arbuscular mycorrhizal colonization and nodulation improve flooding tolerance in Pteocarpus offianalisJacq. seedlings. Mycorrhiza 17:159-66.

Garcia I, Mendoza R, Pomar MC. 2008. D eficit and excess of soil water impact on plant growth of Ldustenis by affecting nutrient uptake and arbuscular mycorrhizal symbiosis. Plant Soil 304: 117-31.

Gerdemann JW, Nicolson TH. 1963. Spores of mycorrhizal endogone species extracted from soil by wet sieving and decanting. Trans. Brit. Mycol. Soc. 46: 235-44.

G raham LL, Turjaman M, Page SE. 2013. Sharea balangran and Dyea poyyphyla(syn. Dyea lowï) as tropical peat swamp forest restoration transplant species: effects of mycorrhizae and level of disturbance. Wetlands Ecol Manage 21(5):307-21.

Helgason T, Fitter AH. 2009. Natural selection and the evolutionary ecology of the arbuscular mycorrhizal fungi (PhyumGlomeromycta) [DARWIN REVIEW]. JExp Bot60(9): 2465-80.

Hiler EA, van Bavel CHM, Hossain MM, Jordan WR. 1972. Sensitivity of southem peas to plant water deficit at three growth stages. Agron.J. 64:60-4.

Islam MA, Macdonald SE. 2004. Ecophysiological adaptations of black spruce (Pice mariana) and tamarack (Lanix lariana) seedlings to flooding. Trees 18: 35-42.

Iwanaga F, Yamamoto F. 2008. Effects of flooding depth on growth, morphology and photosynthesis in Alnusjaponicaspecies. New For. 35:1-14.

Kartikasari SN, Marshal AJ, Beehler BM. 2012. Ekdøg Papua: Sei Ekdogi Indonesia Jilid VI. Jakarta(ID): Yayasan Pustaka O bor Indonesia dan Conservation International.

Keeley JE. 1980. Endomycorrhizae influence groth of blackgum seedlings in flooded soils. Am J Bot 67(1): 6-9.

Keßler PJA, Bos MM, D aza SECS, Kop A, Willemse LPM, Pitopang R, G radstein SR. 2002. Checklist of woody plants of Sulawesi, Indonesia. Blumea, Suplement 14. Leiden (DE): National Herbarium Nedereland and UniversiteitLeiden branch.p 160.

Kogawara S, Yamanoshita T, Norisada M, Masumori M, Kojima K. 2006. Photosynthesis and photoassimilate transport during root hypoxia in Mdaleara cajupti, a flood-tolerant species, and in Euclyptuscamaldulensis a moderately flood-tolerant species. Tree Physiol. 26:1413-23.

Kozlowski TT. 1984. Responses of woody plants to flooding. In: Kozlowksi TT, editor. FloodingandPlant 
Grouth San D iego(US): A cademic Press. p 129-59.

Kozlowski TT. 1997. Responses of woody plants to flooding and salinity. Tree Physiol Monograph No. $1: 1-29$.

Kreuzwieser J, G essler A. 2010. Global climate change and tree nutrition: influence of water availability [Invited Review: part of an invited issue on tree nutrition]. Tree Physiol 30:1221-34.

Kurniawati P. 2011. Pengaruh pemberian inokulum mikoriza dan pemupukan NPK terhadap pertumbuhan semai longkida (Naudea cientalis L.) pada kondisi tergenang dan tidak tergenang. Skrips. Bogor(ID):InstitutPertanian Bogor.

Lim TK. 2013. Edible Medianal and Non-Medianal Plants Vdume5, Fnits New York (US) : Springer.

Longstreth MMD. 1879. The use of the freezing microtome. Boston Med SurgJ 100:632-36.

Marghescu T. 2001. Restoration of degraded forest land in Thailand: the case of Khao Kho. Unasylva 207 (52):52-6.

Martínez-Alcántara B, Jover S, Q uiñones A, Forner-Giner MÁ, Rodrígues-Gamir J, Legaz F, Primo-Millo E, Iglesias DJ. 2012. Flooding affects uptake and distribution of carbon and nitrogen in citrus seedlings.J Plant Physiol 169:1150-57.

Mawaddah M. 2012. Pertumbuhan kayu putih (Mdaleara leradandron Linn.) dan Longkida (Naudea crettalis Linn.) pada kondisi tergenang air asam tambang. Sknipsi Bogor (ID ):Institut Pertanian Bogor.

Medina CL, Sanches MC, Tucci MLS, Sousa CAF, Cuzzuol GRF, Joly CA. 2009. Erythinaspeciosa(LeguminosaePapilionoideae) under soil water saturation: morphophysiological and growth responses. Ann Bot. 104:671-80.

Mendoza R, Escudero V, Garcia I. 2005. Plant growth, nutrient acquisition and mycorrhizal symbioses of a waterlogging tolerant legume (Lctus gaber Mill.) in a saline-sodic soil. Plant Soil 275:305-15.

Muok BO, Ishii T. 2006. Effect of arbuscular mycorrhizal fungi on tree growth and nutrient uptake of Sdeocarya bime under water stress, salt stress and flooding.J.Jpn. Soc. Hortic. Sci. 75:26-31.

Nakai A, Yurugi Y, Kisanuki H. 2010. Stress responses in Salix gaalistyla cuttings subjected to repetitive alternateflooding and drought. Trees 24:1087-95.

Neto D, Carvalho LM, Cruz C, Martins-Loução MA. 2006. How do mycorrhizas affect $\mathrm{C}$ and $\mathrm{N}$ relationships in flooded Astertipodiumplants?. Plant Soil 279:51-63.

Nielsen JL, Stewart BR, Pearce DW, Letts MG, JiskootH. 2010. Streamside trees: responses of male, female and hybrid cottonwoods to flooding. Tree Physiol 30:1479-88.
O sundina MA. 1998. Nodulation and growth of mycorrhizal Casuarima equistifdiaJ.R. and G. First in response to flooding. Biol Fertil Soils 26:95-9.

Parolin P. 2009. Submerged in darkness: adaptations to prolonged submergence by woody species of the Amazonian floodplains. Annals of Botany 103:35976.

Parolin P, F Wittmann. 2010. Struggle in the flood: tree responses to flooding stress in four tropical floodplain systems. AoB Plants 2010: plq003, doi: 10.1093/ aobpla/ plq003.

Petty AM, Douglas MM. 2010. Scale relationships and linkages between woody vegetation communities along a large tropical floodplain river, north Australia.J Tropical Ecol 26:79-92.

Qiang-Sheng $\mathrm{Wu}$, Ying-Ning Zou, Yong-Ming Huang. 2012. The arbuscular mycorrhizal fungus Diversispora spurca ameliorates effects of waterlogging on growth, root system architecture and antioxidant enzymeactivities of citrus seedlings. Fungal Ecology 6 (1): 37-43.

Sah S, S Reed, K Jayachandran, C D unn, JB Fisher. 2006. The effect of repeated short-term flooding on mycorrhizal survival in snap bean roots. HortScience 41:598-602.

Secilia J, Bagyaraj DJ. 1994. Selection of efficient vesiculararbuscular mycorrhizal fungi for wetland rice - a preliminary screen. Mycorrhiza 4:265-68.

Smith SE, Read DJ. 2008. Mycomizal SymbiosisThirdEdition New York(US): Academic Press.

Stevens KJ, Spender SW, Peterson RL. 2002. Phosphorus, arbuscular mycorrhizal fungi and performance of the wetland plant Lythrum salicaria L. under inundated condition. Mycorrhiza 12: 277-83.

Stevens KJ, Christopher BW, Joel AJ. 2011. Effects of arbuscular mycorrhizal fungi on seedling growth and development of two wetland plants, Bidans frondbsaL., and Ediptaprostrata (L.) L., grown under three levels of water availability Mycomiza 21:279288.

Sudha K, Ammani K. 2010. Arbuscular mycorrhizal fungi in medicinal plants in Thrissur district, Kerala. Mycorrhiza News 21(4): 13-8.

Tanaka K, Masumori M, Yamanoshita T, Tange T. 2011. Morphological and anatomical changes of Mdalera cajuputiunder submergence. Trees 25: 695-704.

Van Splunder I, Voesenek LACJ, Coups H, De Vries XJA, Blom CWPM. 1996. Morphological responses of seedlings of four species of Salicaceae to drought. Can.J. Bot 74: 1988-95.

Walker C, Mize CW, Menabb HS Jr. 1982. Population of Endogonaceous fungi at two location in Central Iowa. Can.J. Bot. 60:2518-29. 